\title{
16S-23S RDNA: POLYMORPHISMS AND THEIR USE FOR DETECTION AND IDENTIFICATION OF XYLELLA FASTIDIOSA STRAINS
}

\author{
Juliana Camargo Martinati ${ }^{1 *}$; Flávia Tereza Hansen Pacheco ${ }^{1}$; Vitor Fernandes Oliveira de Miranda ${ }^{2}$; Siu Mui Tsai ${ }^{1}$ \\ ${ }^{1}$ Cell and Molecular Biology Laboratory of Agriculture Nuclear Energy Center - (CENA/USP) - Piracicaba, São Paulo, Brazil; \\ ${ }^{2}$ Mogi das Cruzes University - UMC - São Paulo, Brazil
}

Submitted: February 01, 2006; Returned to authors for corrections: September 21, 2006; Approved: January 18, 2007

\begin{abstract}
Strains of Xylella fastidiosa from several hosts (coffee, citrus, grape, almond, oleander, peach, plum, etc.) were characterized by analyzing the content of the nucleotide sequences of $16 \mathrm{~S}-23 \mathrm{~S}$ rDNA (coding for a small subunit ribosomal RNA) spacer region (ITS). Current methods for sequencing the ITS region yields partial sequences that do not contribute with significant information. According to this fact, new primers have been designed in order to obtain a complete sequence and facilitate the sequencing. The complete 16S-23S sequences from 08 strains were amplified through PCR using the primers designed in our lab. The 16S-23S sequences obtained were compared with 52 others sequences entries in GenBank database. The results revealed a higher level of variation than that found in $16 \mathrm{~S}$ gene sequences, with similarity values ranging from $0.79-1.00$. The dendogram based on similarity data revealed 5 main groups. This spacer sequence contains two genes for tRNA (tRNA ala and tRNA ${ }^{\text {ile }}$ ). The sequence analysis of the tRNA content showed a conserved region with a few differences in the nucleotide composition.
\end{abstract}

Key words: Genetic diversity, 16S-23S rDNA, intergenic spacer, identification, detection.

\section{INTRODUCTION}

Xylella fastidiosa (29) is a fastidious gram-negative bacterium that causes a range of economically important plant disease in many crops such as citrus, grapevine, coffee, almond, peach among others. Its pathogenicity mechanism is thought to be by the obstruction the plant's vascular systems thus inducing water stress and nutritional disorders (17). It is present in Brazil where it causes Coffee Leaf Scorch (CLS), Plum Leaf Scald (PLS) but the most economically important is Citrus Variegated Chlorosis (CVC). This bacterium is transmitted by different insect vectors, mainly sharpshooters (16).

Although all $X$. fastidiosa strains are classified as one species, molecular methods of DNA profile has been successfully made in order to distinguish different groups of strains such as DNA homology (19), RFLP (5), RAPD (2) and VNTR analysis (7). Pooler et al. (26) distinguished five groups of $X$. fastidiosa using RAPD.
The rDNA genetic locus is extremely important in all organisms and there is sufficient conservation for it to be used in a universal characterization of relationship of many bacterial species $(4,12,20)$. The sequence analysis of the small subunit, 16S rDNA, has been frequently used for determining inter- and intraspecific relationships. However insufficient diversity is often found in the $16 \mathrm{~S}$ gene and thus genetic relationship of closely related species cannot be well defined (27). Analysis of the 16S-23S intergenic spacer could overcome this problem due to its higher variation in length and sequence and depending on the degree of variation the polymorphisms found can be used for differentiation at the genus species or strains levels. Indeed the analysis of this region has successfully differentiated strains of many groups of bacteria $(3,18)$, and sequences of this spacer region of many species have become available for comparison.

In this study, the relationships among sixty strains of $X$. fastidiosa, isolated from several hosts were analyzed in an

*Corresponding Author. Mailing address: Laboratório de Biologia Celular e Molecular, Centro de Energia Nuclear na Agricultura (CENA/USP), ZIP CODE 13400-970, POBOX 96 Piracicaba, São Paulo, Brazil. Tel.: (19) 3429-4640. E-mail: jumarti@cena.usp.br 
attempt to verify the genetic diversity of Xylella strains based on the 16S-23S rDNA intergenic region. Due to the difficulty in sequencing this spacer region with the standard primers, we have designed our own primer pair that has facilitated the recording in the sequencing, turning the method faster and easier because we didn't have to clone our PCR products.

\section{MATERIALS AND METHODS}

Bacterial strains and culture conditions. Eight strains of $X$. fastidiosa isolated from coffee, citrus, mulberry, almond, periwinkle, ragweed, grapevine and elm were sequenced in this study (Table 1). These strains were supplied by Fundação André Tosello and were cultivated in solid PW agar medium for a period from 7 to 10 days at $28^{\circ} \mathrm{C}$.

DNA extraction for PCR. Bacterial DNA was extracted using CTAB buffer according to Doyle and Doyle protocol (10). The samples were visualized under ultra-violet light and the DNA concentration was determined by comparison with the molecular marker pGEM plasmid in ethidium-bromidestained $1.0 \%$ agarose gel.

Amplification of the 16S-23S rDNA. The primer pair for amplification of the 16S-23S intergenic spacer of X. fastidiosa was designed based on the flanking sequences of the 16S-23S intergenic spacer of the strain $\mathrm{X} 0$ available in the GenBank (NCBI) and it has been chosen 20 oligonucleotides arbitrarily using the Primer3.output program (NCBI http://primer3.cgi.htm). The 16S23S-spacer region was amplified by PCR using the primers designed in our lab. The forward primer sequence was 16S23SF (5' GAT GAC TGG GGT GAA GTC GT 3') and of the reverse primer was 16S-23SR (5' GAC ACT TTT CGC AGGCTACC 3'). Amplifications were performed in a $25 \mu \mathrm{L}$ reaction containing $100 \mathrm{ng}$ of DNA template, $0.5 \mu \mathrm{M}$ each primer, $100 \mu \mathrm{M}$ deoxynucleoside triphosphates, $2.5 \mathrm{mM} \mathrm{MgCl} 2,0.5 \mathrm{U}$ Taq DNA polymerase, 1X Buffer. ADNA Thermal Cycler (GeneAmp® PCR
System 9700 Applied Biosystems) was used with 1 cycle of 4 min at $94^{\circ} \mathrm{C}, 40$ cycles at $94^{\circ} \mathrm{C}$ for $40 \mathrm{~s}, 52^{\circ} \mathrm{C}$ for $40 \mathrm{~s}$ and $72^{\circ} \mathrm{C}$ for $1 \mathrm{~min}$, and a final extension of $2 \mathrm{~min}$ at $72^{\circ} \mathrm{C}$. A $5 \mu \mathrm{L}$ aliquot of the PCR products was combined with $2 \mu \mathrm{L}$ loading buffer and visualized on ethidium bromide-stained $1.0 \%$ agarose gels in TE buffer at 3.5 V.cm-1. The molecular marker 1Kb Plus DNA Ladder (Life Technologies) was used to determine the molecular weight of the PCR products and to quantify by comparison. The gel stained with ethidium-bromide was photographed on a UV transluminator (Fluor-S Multimager System - Bio Rad).

Sequencing methods. The purification of the PCR products was made by using the GFX PCR DNA and Gel Purification Kit (Pharmacia Biotech). The amplicons were bidirectionaly sequenced by the dideoxy chain terminator method using a thermocycler (Perkin-Elmer Applied Biosystems). The reactions for sequencing were performed in a total volume of $10 \mu \mathrm{L}$ containing 30-50 ng DNA, $5 \mu \mathrm{M}$ each primer; $2 \mu \mathrm{LABI}$ PRISM Big Dye terminator cycle sequencing ready reaction Kit (Perkin Elmer), and $2 \mu \mathrm{L} 2.5 \mathrm{X}$ buffer (Tris-HCL $200 \mathrm{mM} \mathrm{pH} 9.0 ; \mathrm{MgCl} 2$ $5 \mathrm{mM}$ ). The reactions were performed with the same condition as the amplified PCR. The products were precipitated with isopropanol $75 \%$ and washed with ethanol $70 \%$. Sequence reaction mixtures were recorded using the ABI Prism 3100 Genetic Analyzer (Perkin-Elmer Applied Biosystems) and repeated five times for all the strains tested.

Sequence analysis. The 16S-23S spacer regions of eight $X$. fastidiosa strains sequenced in this study were analyzed with the BLASTN (1) program, a subprogram of BLAST, through the network service of the National Center for Biotechnology Information (http://www.ncbi.nlm.nih.gov) against nonredundant sequences. The sequences that we determined were aligned with 52 other $X$. fastidiosa $16 \mathrm{~S}-23 \mathrm{~S}$ sequences available in the GenBank (Table 2) using the EasyAlign (25) program that employs the MALIGN algorithm (32,33). As to the weight to gaps, it was attributed 2 to leading and trailing, 3 to internal and 2 to

Table 1. X. fastidiosa strains used for diversity analysis based on rDNA spacer region and their 16S-23S rDNA sequence accession numbers.

\begin{tabular}{cccccc}
\hline Strain & Host & Geographical origin & Source & ATCC ** & GenBank accession numbers \\
\hline CI.X0* $^{*}$ & Citrus & Macaubal, SP, BR & IAC & & AF237651 \\
P3* & Coffee & Pindorama, SP, BR & CCT 6740 & & AY388464 \\
MUL-1* & Mulberry & Massachusetts, USA & CCT6744 & ATCC 35868 & AY388467 \\
ALS-BC* & Almond & California, USA & CCT6746 & ATCC 35870 & AY388465 \\
ELM-1* & Elm & Washington, USA & CCT6748 & ATCC 35873 & AY388468 \\
RGW-R* & Ragweed & Florida, USA & CCT6749 & ATCC 35876 & AY388469 \\
PWT-22* & Periwinkle & Florida, USA & CCT6751 & ATCC 35878 & AY388470 \\
& Grapevine* & Califórnia, USA & CCT6068 & & AY388466 \\
\hline
\end{tabular}

*Strains sequenced in this study; \#Coleção de Culturas Tropicais do Acervo da Fundação André Tosello - Campinas/SP; ** ATCC, American Type Culture Collection (Manassas, VA, USA); L.W. Moore, Oregon State University (Corvallis, OR, USA). 
Table 2. X. fastidiosa strains available in GenBank included for comparison in the phylogenetic analysis based on rDNA spacer region and their 16S-23S rDNA accession numbers.

\begin{tabular}{|c|c|c|c|}
\hline Strain & Host & $\begin{array}{l}\text { GenBank 16S-23S } \\
\text { accession numbers }\end{array}$ & $\begin{array}{c}\text { Geographical } \\
\text { origin }\end{array}$ \\
\hline Maple & Acer macrophyllum & $m \quad \mathrm{AF} 073219$ & California \\
\hline PL.788 & Plum & AF203395 & Georgia \\
\hline Plum2\#4 & Plum & AF073209 & Georgia \\
\hline ALS1 & Almond & AF073240 & California \\
\hline ALS2 & Almond & AF073243 & California \\
\hline ALS3 & Almond & AF073244 & California \\
\hline ALS4 & Almond & AF073245 & California \\
\hline ALS5 & Almond & AF073246 & California \\
\hline ALS6 & Almond & AF073247 & California \\
\hline ALS7 & Almond & AF073248 & California \\
\hline ALS9 & Almond & AF073249 & California \\
\hline Manteca & Almond & AF073241 & California \\
\hline ContraCosta & Almond & AF073250 & California \\
\hline Tulare & Almond & AF073242 & California \\
\hline CO.01 & Coffee & AF203394 & São Paulo \\
\hline Oak 88-9 & Oak & AF 073210 & Florida \\
\hline Oak 92-3 & Oak & AF073211 & Florida \\
\hline Oak 92-10 & Oak & AF073212 & Florida \\
\hline OLS\#2 & Oak & AF073213 & Georgia \\
\hline Stucky & Oak & AF073214 & Georgia \\
\hline CI.52 & Citrus & AF203393 & São Paulo, BR \\
\hline CI.11067 & Citrus & AF237650 & Paraná, BR \\
\hline Ann1 & Oleander & AF 073215 & California \\
\hline PF1 & Oleander & AF073216 & California \\
\hline $\mathrm{T} 1 \mathrm{c}$ & Oleander & AF073217 & California \\
\hline TR1 & Oleander & AF073218 & California \\
\hline $5 \mathrm{~S} 2$ & Peach & AF 073206 & Georgia \\
\hline $5 \mathrm{R} 1$ & Peach & AF073207 & Georgia \\
\hline $4 \mathrm{~S} 3$ & Peach & AF073208 & Georgia \\
\hline PE.PLS & Pear & AF203396 & Taiwan \\
\hline GR8935 & Grapevine & AF203397 & California \\
\hline ConnCreek & Grapevine & AF073225 & California \\
\hline Stags Leap & Grapevine & AF073226 & California \\
\hline Fetzer & Grapevine & AF073227 & California \\
\hline STL & Grapevine & AF073228 & California \\
\hline Santa Cruz & Grapevine & AF073229 & California \\
\hline Meyley & Grapevine & AF073230 & California \\
\hline UCLA & Grapevine & AF073231 & California \\
\hline Preston Ranch & Grapevine & AF073232 & California \\
\hline VinoF & Grapevine & AF073233 & California \\
\hline Medeiros & Grapevine & AF073234 & California \\
\hline Traver & Grapevine & AF073235 & California \\
\hline Moore Park & Grapevine & AF073236 & California \\
\hline Douglas & Grapevine & AF073237 & California \\
\hline Oxford & Grapevine & AF073238 & California \\
\hline Hopland & Grapevine & AF073239 & California \\
\hline PD95-2 & Grapevine & AF073220 & California \\
\hline PD95-4 & Grapevine & AF073221 & California \\
\hline PD95-9 & Grapevine & AF073222 & California \\
\hline R116V3 & Grapevine & AF073223 & California \\
\hline Dixon & Grapevine & AF073251 & California \\
\hline R118V3-4 & Grapevine & AF073224 & California \\
\hline
\end{tabular}

extra gaps. Transitions and transversions have no differential weight. Heuristic search was made (score 2, build) and the branch swapping was made through $s p r$. The sequences were randomized to avoid local minima. Detection of tRNA genes was performed with the tRNA scan-SE program (v. 1.11) (23) through the network service of the Pasteur Institute (Paris, France) (http:// www.pasteur.fr). The 16S-23SrDNA nucleotide sequences of the eight Xylella strains were submitted to the GenBank and have been assigned the accession numbers reported in Table 1 . The dendogram was constructed with the TreeView (Page, 1998) program, and the PE.PLS strain was used as outgroup.

\section{RESULTS AND DISCUSSION}

Analysis of the PCR products using the primers designed. The amplicons of the 16S-23S region yielded a unique band of $650 \mathrm{bp}$ for all the strains tested using the primers designed in our lab (Fig. 1). Although it is known that $X$. fastidiosa has two $r r n$ locus $(6,28)$, in our case, only one PCR product was obtained, indicating that these two $r r n$ copies did not differ in length. It is assumed that bacteria with a fewer copies of the rrn operon are more fastidious than those with more copies. Some slowgrowing bacteria including Archea, Mycobacterium has only one copy of the rrn operon (13).

The use of complete 16S-23S rDNA sequences using a unique set of primers without cloning made this research easier and less time consuming. It has been tried to use a set of primers proposed by Honeycutt et al. (15) to amplify the 16S-23S spacer

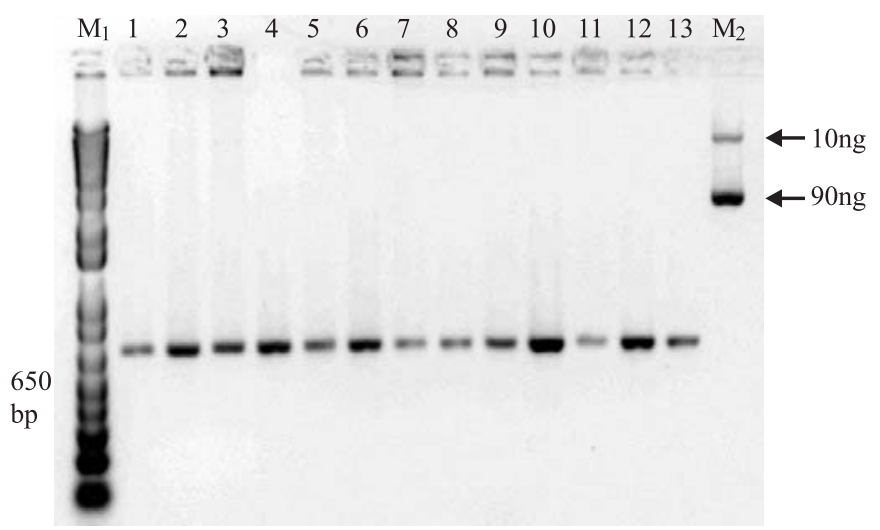

Figure 1. Gel electrophoresis of the amplified rDNA internal transcribed spacer (ITS) region of 7 Xylella fastidiosa strains. Fragments with 650 bp. $\mathrm{M}_{1}$-Molecular marker 1Kb Plus DNA Ladder; 1-13 Xylella fastidiosa strains: 1-Citrus (X0); 2-4-Coffee (6738, 6740, 6755); 5-7-Grapevine (6068, 6752, 6753); 8-9Mulberry (6744, 6745); 10-Almond (6746); 11-Elm (6748); 12Ragweed (6749); 13-Periwinkle (6751); $\mathrm{M}_{2}$ - Molecular marker pGEM. 
region, but we could not recovery the complete sequence in the sequencing because the fragments generated were very long $(1.1 \mathrm{Kbp})$. With the current DNA sequence technology, internal primers are generally required for complete sequencing of fragments in excess of $1 \mathrm{Kbp}$. Since the average length of the fragments yielded by Honeycutt primers is approximately 1.1 $\mathrm{Kbp}$, internal primers are required to capture all encoded information. This results in additional time and expense and may make this approach financially impractical when a large number of isolates requires information.

Analysis of the 16S-23S spacer region. The complete ITS sequence of eight $X$. fastidiosa strains was determined by directly sequencing PCR amplified 16S-23S rDNA spacer products. The use of a direct sequencing from the PCR products have reduced the costs, since it is not necessary to use cloning vectors to sequence short PCR products (less than $700 \mathrm{bp}$ ). The PCR fragment was sequenced in both directions and the ends corresponding to part of the $16 \mathrm{~S}$ and $23 \mathrm{~S}$ genes were eliminated according to X0 $16 \mathrm{~S}-23 \mathrm{~S}$ sequence. After the exclusion of a flanking sequence, a fragment of approximately 510 bases containing the $16 \mathrm{~S}-23 \mathrm{~S}$ rDNA region of all strains was obtained. The BLAST search, using the spacer sequences as query, has identified all the available 16S-23S Xylella fastidiosa spacer sequences in the current GenBank database with similarity values ranging from 0.79 to 1.00 . The 16S-23S sequences, which we have determined, have been deposited in the GenBank Data Library under the accession number shown in Table 1. The eight strains sequenced in this study were also aligned with 52 other $X$. fastidiosa sequences available in the GenBank (Table 2) (For the complete alignment of all the sequences studied see reference 24).

Analysis of most $X$. fastidiosa sequences revealed some variable sites, 17 in the entire sequence, which included base additions, deletions or substitutions The similarity levels found in the 16S-23S rDNA spacer regions for different Xylella fastidiosa strains are shown in Table 3. Not all of the sequences analyzed are shown in the table (to visualize all the similarity values among the Xylella strains see reference 24). These results revealed that the highest level of variation was found between the pear strain (PE.PLS) and the others strains with similarity values ranging from 0.793 to 0.812 . The closest strain to pear was the citrus (X0) with similarity values of 0.812 and the lowest value was found between the pear and grapevine strains (6068) with similarity values of 0.793 .

Some others strains presented low similarity value such the grapevine strain 6068 when compared with the citrus strain CI.X0, the coffee strain 6740, the almond strains, ALS9, ALS7, ALS6, ALS5, ALS4, ALS3, ALS2, Contra Costa, Dixon, and the oak strains Stuck, OLS\#2, 92-10, 92-3 and 88- 9 with similarity values of 0.96 . The periwinkle strain also showed low similarity values ranging from 0.95 to 0.96 and was the strain with the second lowest similarity value.

Some strains showed similarity values of 1.00 . These strains have the same ITS sequence and thus grouping themselves in the same cluster such the most grapevine strains (except 6068, GR 8935), the citrus strains CI X0 and CI 11067, all the oleander strains, all the oak strains, the peach - most almond strains (except ALS1, Manteca e Tulare).

Table 3. Similarity values among $X$. fastidiosa strains on the basis of 16S-23S rDNA sequences.

\begin{tabular}{|c|c|c|c|c|c|c|c|c|c|c|c|c|c|c|c|c|c|}
\hline & CI & $\mathrm{CO}$ & GR & GR & & ALM & & OLE & OAK & PL & PEA & MA & MUL & ELM & PRW & RGW & $\mathrm{PE}$ \\
\hline Seq.-> & CI.X0 & 6740 & 6068 & Trave & 6746 & ALS9 & ALS1 & Ann1 & 88-9 & PL.78 & $5 \mathrm{~S} 2$ & Acer & 6744 & 6748 & 6749 & 6751 & PE.PL \\
\hline CI.X0 & 1.000 & 0.994 & 0.964 & 0.968 & 0.984 & 0.982 & 0.968 & 0.968 & 0.980 & 0.992 & 0.982 & 0.968 & 0.976 & 0.972 & 0.968 & 0.986 & 0.812 \\
\hline 6068 & - & - & 1.000 & 0.976 & 0.964 & 0.962 & 0.976 & 0.968 & 0.961 & 0.972 & 0.962 & 0.976 & 0.984 & 0.980 & 0.949 & 0.966 & 0.793 \\
\hline Trave & - & - & - & 1.000 & 0.980 & 0.986 & 1.000 & 0.992 & 0.984 & 0.976 & 0.986 & 1.000 & 0.988 & 0.984 & 0.953 & 0.970 & 0.797 \\
\hline 6746 & - & - & - & - & 1.000 & 0.994 & 0.980 & 0.980 & 0.992 & 0.988 & 0.994 & 0.980 & 0.976 & 0.972 & 0.968 & 0.986 & 0.806 \\
\hline Ann1 & - & - & - & - & - & - & - & 1.000 & 0.984 & 0.976 & 0.986 & 0.992 & 0.980 & 0.976 & 0.953 & 0.970 & 0.797 \\
\hline 88-9 & - & - & - & - & - & - & - & - & 1.000 & 0.984 & 0.998 & 0.984 & 0.972 & 0.968 & 0.964 & 0.982 & 0.802 \\
\hline PL.78 & - & - & - & - & - & - & - & - & - & 1.000 & 0.986 & 0.976 & 0.984 & 0.980 & 0.972 & 0.990 & 0.810 \\
\hline $5 \mathrm{~S} 2$ & - & - & - & - & - & - & - & - & - & - & 1.000 & 0.986 & 0.974 & 0.970 & 0.966 & 0.984 & 0.804 \\
\hline Acer & - & - & - & - & - & - & - & - & - & - & - & 1.000 & 0.988 & 0.984 & 0.953 & 0.970 & 0.797 \\
\hline 6744 & - & - & - & - & - & - & - & - & - & - & - & - & 1.000 & 0.992 & 0.961 & 0.978 & 0.804 \\
\hline
\end{tabular}

CI - citrus; CO - coffee, GR - grapevine; ALM - almond; OLE - oleander; PL - plum; PEA - peach; MA - maple; MUL - mulberry; PRW periwinkle; RGW - ragweed; PE - pear. 
By analyzing the dendogram based on similarity data (Fig. 2 ) it could be recognized the existence of six groups: group 1 (bootstrap 89\%) comprises the most grapevines strains, three almond strains (ALS1, Manteca e Tulare) and the maple strain;

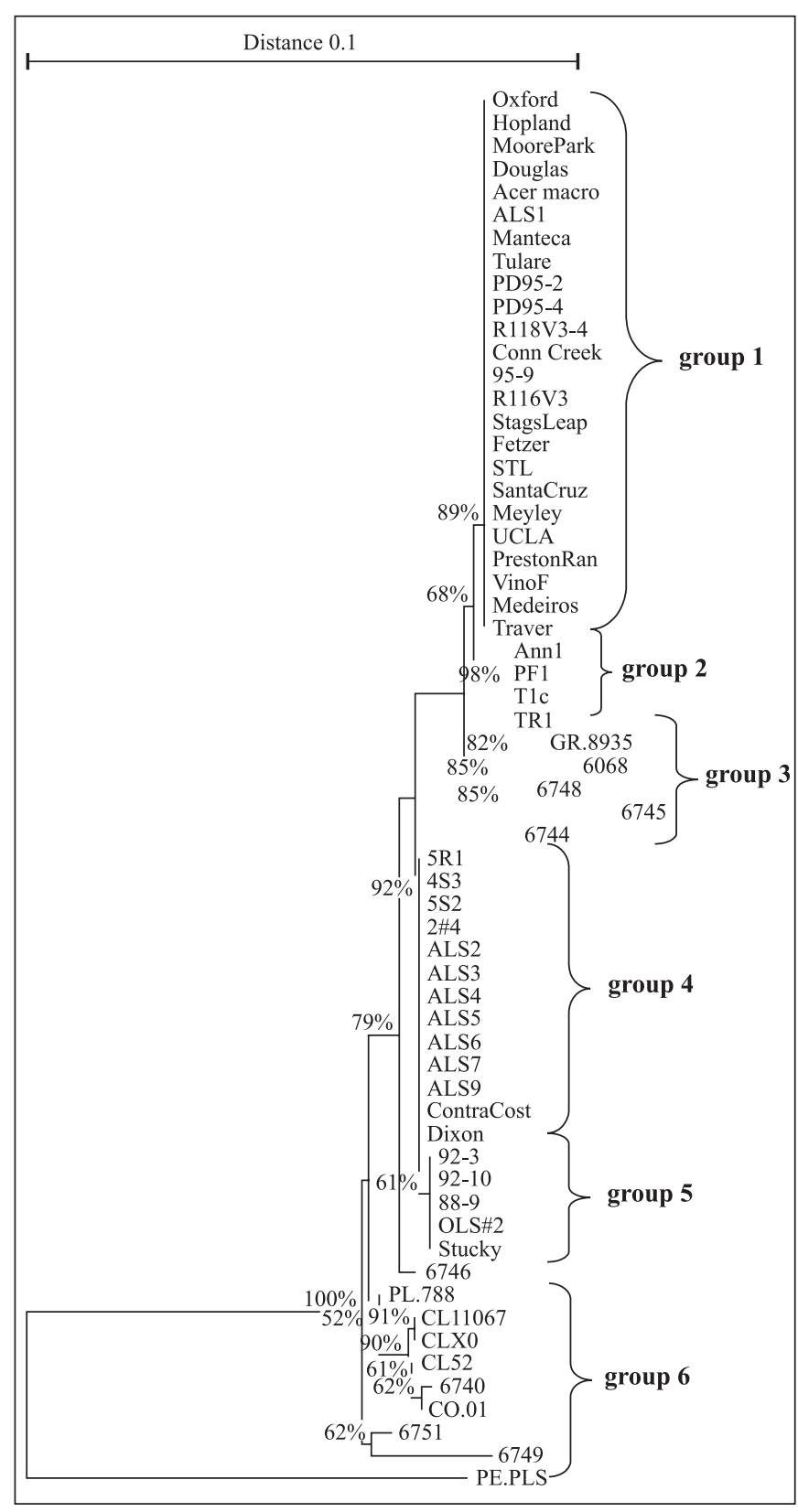

Figure 2. Dendogram based on the nucleotide sequence of the $16 \mathrm{~S}-23 \mathrm{~S}$ rDNA intergenic spacer of $X$. fastidiosa strains from different host. The information was based on distance data obtained by sequence analysis of the ITS region. The scale bar indicates relative similarity value between strains and the percentage values indicates the bootstrap value. group 2 (bootstrap 98\%) comprises the oleander strains; group 3 (bootstrap 85\%) comprises two grapevine strains (GR8935 and 6068), the elm strain and the mulberry strains; group 4 (bootstrap 92\%) comprises the peach strains and the most almond strains, group 5 (bootstrap 61\%) comprises the oak strains and the group 6 (bootstrap 52\%) comprises the citrus coffee-ragweed-periwinkle-plum (PL.788) strains.

The strains isolated from peach (5R1 4S3, 5S2), plum (2\#4) and almond (ALS9, ALS7, ALS6, ALS5, ALS4, ALS3, ALS2, Dixon, Contra Costa) showed identical sequences although these strains belongs to different hosts. This result was also obtained by Hendson (14). The same situation occurs among the almond (ALS1, Manteca, Tulare), Acer and the most grapevines strains (Except for the 6068 and GR8935 strains). This similarity put them in the same cluster in the dendogram. The almond and grapevine strains are thought to be caused by the same or similar strains of $X$. fastidiosa but anomalies have been noted. Hendson (14) suggest that some almond strains (e.g., ALS1, Manteca, and Tulare) may cause either Pierce Disease or Almond Leaf Scorch under natural conditions, but other almond strains probably cause disease mostly in fieldgrown almonds.

Many authors previously reported closest relation between coffee and citrus strains. Li et al. (21) confirmed that the citrus strains can produce the full range of symptoms observed in coffee plants. Lopes et al. (22) showed that the tobacco plants inoculated with the citrus strain also produce the typical leaf symptoms, however the tobacco plants inoculated with the coffee strains showed slight symptoms. They attribute this differential response in a same host due a distinct mechanism of pathogenicity in tobacco plants.

Unexpectedly, the strains 2\#4 e PL.788, isolated from the same host and geographic region, showed 7 differences in the sequence, what puts them in very distinct genetic groups. The detection of different genotypes in the same host may indicate the possibility of diverse response in the host-pathogen interaction. In a study based on RAPD data, the plum strain of $X$. fastidiosa from the United States clustered with the grape strain from the same country whereas a plum strain from Brazil grouped with citrus and coffee strains from Brazil (8). Lopes et $a l$. (22) by analyzing the relationship among citrus, coffee and plum strains from Brazil showed that tobacco plants inoculated with these strains responds differentially to infection suggesting that distinct mechanism must be involved in the patogenicity.

Also among the grapevine strains, except for the 6068 and GR 8935, the sequencing results revealed identical sequences. Both strains were different from the others in 11 bases and four indels only,

With the exception of the almond (ALS1, Manteca, Tulare, 6746), plum, citrus and coffee strains, the other Xylella fastidiosa strains from the same host showed identical 16S-23S rDNA sequences. The similarity values within the coffee (6740) and 
almond (6746) strains sequenced in this study in comparison with the sequences obtained from GenBank was 0.98 and 0.99 respectively. The periwinkle (6751), ragweed (6749), mulberry (6744) and elm (6748) strains sequenced in this study could not be compared with the strains isolated from the same host because the 16S-23S sequences are unavailable in the GenBank. This study was the first research that sequenced the ITS region from these strains.

Regarding the 6746 strain, sequenced in our laboratory, it revealed eight different bases (4 translocations, 2 transversions e 2 indels) when compared to the strains ALS1, Manteca and Tulare, and only 3 translocations, among the other almond strains. The ALS1, Manteca and Tulare strains have the same sequence as the strains isolated from grapevine. The genetic similarity among these strains is reported in some studies, in which the PD is thought to be caused by the same or similar strains of Xylella fastidiosa (9).

Based on tRNA scan program, the analysis of the aligned sequences has revealed that the intergenic spacer region of all Xylella fastidiosa strains contained two genes for tRNA (tRNA ala e tRNA ${ }^{\text {ile }}$ ), which are found in most of the gramnegative bacteria (Gutler \& Stanisch, 1996) with approximately 72 and 74 bases for the tRNA alanine and isoleucine genes, respectively (Complete tRNAs sequences are available in reference 24). By analyzing the content of these genes it was revealed that the strains 6068 (grapevine), GR 8935 (grapevine), coffee (CO.1 01), 6749 (ragweed), 6751 (periwinkle) and PE.PLS (pear) showed differences in the composition of nucleotides. In the strain 6068, it was found differences in the positions 263 and 285 for tRNA ${ }^{\text {ile }}$, and in the positions 330, 347, 386, 397 for tRNA $^{\text {ala }}$. Only one difference was found in the GR 8935 strain (position 263) for the gene of tRNA ${ }^{\text {ile }}$. The coffee strain CO.01 showed just one difference for tRNA ${ }^{\text {ile }}$ (position 256). The differences found in the strain 6749 were only revealed in the tRNA ${ }^{\text {ala }}$ and they showed the largest number of variations (positions 333, 348, 353, 365, 367 and 396). The periwinkle strain (6751) showed only one difference for tRNA ala gene (position 373). Only one difference was found in the pear strain for the tRNA $^{\text {ile }}$ gene (position 270). and two in the tRNA ${ }^{\text {ala }}$ (positions 339 and 358).

The use of the 16S-23S rDNA as a tool to infer relations between microorganisms is ten times greater than the polymorphism rate of the $16 \mathrm{~S}$ rDNA (20). Using the sequencing of the ITS region, it could be possible to draft a relationship to some hosts and has revealed a higher degree of genetic polymorphism. This region supplies information regarding intraspecific relations and allows researchers to detect recently divergences while the $16 \mathrm{~S}$ gene is a good tool to infer interspecific relationships.

In addition, the ITS has the potential to be used for environmentally significant species and strain differentiation. Hence, ITS sequences have been proposed as a useful supplement when 16S rDNA shows insufficient diversity to differentiate recently diverged species. This sequence does not code for a final product, but it has an important processing function in forming pre-RNAs. As a consequence, there is presumably some functional selective pressure for conservation of this region. This assumption is consistent with the stability of species-specific ITS signatures found with high reproducibility in different strains. The evolutionary rate of the ITS is higher than that of $16 \mathrm{~S}$ rRNA, and rearrangements in the central region are relatively recent.

The principal goal of our study was to investigate the level of ITS polymorphism and thereby assess the utility of this target for Xylella fastidiosa detection and identification. Unlike a 16S rDNA based PCR, in which the genus-specific primers are separated by a long stretch of target sequence, an ITS-based PCR should result in a smaller PCR product and in more efficient and sensitive target amplification.

The conventional methods for identifying bacteria based on growth characteristics and biochemical tests are timeconsuming and often are ambiguous in their interpretation. Currently, the widely accepted strategy formulated to improve methods of bacterial strain identification includes analysis of the gene encoding rDNA.

This study demonstrates that the ITS of the genus Xylella exhibits variations in length and, importantly, shows a reasonable number of base substitutions and insertion or deletion sites. Unfortunately, ITS sequence analysis failed to discriminate some strains belonging to the same host, but in general it is possible to discriminate strains from different hosts. This disappointing, yet not surprising, finding stands in agreement with $16 \mathrm{~S}$ rDNA data, according to which Xylella fastidiosa is a unique species.

\section{RESUMO}

\section{S-23S rDNA: Polimorfismos e sua aplicação na detecção e identificação de linhagens de Xylella fastidiosa}

Linhagens de Xylella fastidiosa de diferentes hospedeiros (café, uva, amêndoa, ameixa, etc.) foram caracterizados analisando as sequências de nucleotídeos do espaço intergênico 16S-23S (ITS). Os métodos atuais para o sequenciamento da região ITS produzem fragmentos parciais das sequências que não contribuem com informações significantes. Em vista disso, novos primers foram desenhados a fim de obter uma sequência completa e facilitar o sequenciamento. A sequencia completa da região ITS de 08 linhagens de X. Fastidiosa foram amplificadas via PCR, sequenciadas e comparadas com outras 52 sequencias depositadas no GenBank. Os resultados revelaram um alto nível de variação sendo maior que os níveis encontrados quando se utiliza o gene $16 \mathrm{~S}$ para este tipo de análise, com 
valores variando entre 0.79 a 1.00 . O dendograma baseado em dados de similaridade agrupou as linhagens de $X$. fastidios $a$ em 5 grupos principais. Duas sequencias codificadoras de tRNA's foram encontradas (tRNA ala e tRNA ${ }^{\text {ile }}$ ) e mostram-se conservadas entre as linhagens analisadas com pouca diferença entre a composição nucleotídica.

Palavras chave: Diversidade genética, 16S-23S rDNA, espaço intergênico, identificação, detecção

\section{REFERENCES}

1. Altshul, S.F.; Madden, T.L.; Schaffer, A.A.; Zhang, J.; Zhang, Z.; Miller, W.; Lipman, D.L. (1997). Gapped BLAST and PSI-BLAST A new generation of protein database search programs. Nucleic Acids Res., 25, 3389-3402.

2. Banks, D.; Albibi, R.; Chen, J.; Lamikanra, O.; Jarret, R.L.; Smith, B.J. (1999) Specific detection of Xylella fastidiosa Pierce's disease strains. Curr Microbiol., 39, 85-88.

3. Barry, T.G.; Colleran, G.; Glenon, M.; Dunican, L.; Gannon, F. (1991) The $16 \mathrm{~S} / 23 \mathrm{~S}$ ribosomal spacer as a target for DNA probes to identify eubacteria. PCR Methods Appl., 01, 51-56.

4. Cedergren, R.J.; Gray, M.W.; Abel, Y.; Sankoff, D. (1988) The evolutionary relationships among know life forms. J. Mol. Evol., 28, 98-112.

5. Chen, J.; Chang, C.J.; Jarret, R.L.; Gawel, N. (1992) Genetic variation among Xylella fastidiosa strains. Phytopathol, 82(09), 973-977.

6. Chen, J.; Banks, D.; Jarret, R.L.; J.B. Jones (2000) Evidence for conserved tRNA genes in the 16S-23S rDNA spacer sequence and two rrn operons of Xylella fastidiosa. Can. J. Microbiol., 46, 1171-1175.

7. Coletta-Filho, H.D.; Takita, M.A.; Souza, A.A.; Aguilar-Vildoso, C.I.; Machado, M.A. (2001) Differentiations of strains of Xylella fastidiosa by a variable number of tandem repeat analysis. Appl. Environ. Microbiol., 67(09), 4091-4095.

8. Da Costa PI, Franco FC, Miranda VS, Teixeira DC, Hartung JS (2000) Strains of Xylella fastidiosa rapidly distinguished by arbitraly primed - PCR. Curr. Microbiol., 40, 279-282.

9. Davis, M.J.; Thompson, S.W.; Purcell, A.H. (1979) Etiological role of the xylem-limited bacterium causing Pierce's disease in almond leaf scald. Curr. Microbiol., 6, 309-314.

10. Doyle, J.J.T.; Doyle, J.L. (1990) Isolation of plant DNA from fresh tissue. Focus, 12: 13-18.

11. Felsentein, J. (1985) Confidence limits on phylogenies an approach using the bootstrap. Evolution, 39, 783-791.

12. García Martínez, J.; Acinas, S.G.; Antón, A.I.; Rodriguez Valera, F. (1999) Use of the 16S-23S ribosomal genes spacer region in studies of prokaryotic diversity. J. Microbiol. Methods., 36, 55-64.

13. Gurtler, V.; Stanisich, V.A. (1996) New approaches to typing and identification of bacteria using the $16 \mathrm{~S}-23 \mathrm{~S}$ rDNA spacer region. Microbiol., 142, 3-16.

14. Hendson, M.; Purcell, A.H.; Chen, D.; Smart, C.; Guilhabert, M.; Kirkpatrick, B. (2001) Genetic diversity of Pierce's Disease strains and other pathotypes of Xylella fastidiosa. Appl. Environ. Microbiol., 67(2), 895-903.
15. Honeycutt, R.J.; Sobral, B.W.S.; McClelland, M. (1995) tRNA intergenic spacers reveal polymorphisms diagnostic for Xanthomonas albilineans. Microbiol., 141, 3229-3239.

16. Hopkins, D.L.; Mollenhauer, H.H. (1973) Rickettsia like bacterium associated with Pierce's Disease of grapes. Science, 179, 298-300.

17. Hopkins, D.L. (1989) Xylella fastidiosaA xylem-limited bacterial pathogen of plants. Ann. Rev. Phytopathol., 27, 271-290.

18. Jeng, R.S.; Svircev, A.M.; Myers, A.L.; Beliaeva, L.; Hunter, D.M.; Hubbes, M. (2001) The use of $16 \mathrm{~S}$ and $16 \mathrm{~S}-23 \mathrm{~S}$ rDNA to easily detect and differentiate common gram-negative orchard epiphytes. J. Microbiol. Methods, 44, 69-77.

19. Kamper, S.M.; French, W.J.; Dekloet, S.R. (1985) Genetic relationships of some fastidious Xylem-limited bacteria. Int. J. Syst. Bacteriol., 35(02), 185-188.

20. Leblond-Bouget, N.; Philippe, H.; Mangin, I.; Decaris, B. (1996) $16 \mathrm{~S}$ rRNA and $16 \mathrm{~S}$ to $23 \mathrm{~S}$ internal transcribed spacer sequence analysis reveal inter-and intraspecific Bifidibacterium phylogeny. Int. J. Syst. Bacteriol., 46(01), 102-111.

21. L, W.B.; Pria, W.D.; Teixeira, C. et al. (2001) Coffee leaf scorch caused by a strain of Xylella fastidiosa from citrus. Plant. Dis., 85(5), 501-505.

22. Lopes, S.A.; Sá, R.G.; Torres, S.; Marins, M.; Rodrigues, V.; França, S.C. (2000) Genetic and pathological relationship among Xylella fastidiosa strains. I Simpósio Genoma Funcional da Xylella fastidiosa, Serra Negra, SP. Brazil, p.27.

23. Lowe, T.M.; Eddy, S.R. (1997) tRNAscan-SE: a program for improved detection of transfer RNA genes in genomic sequence. Nucleid. Acids. Res., 25(5), 955-964.

24. Martinati, J.C. (2003) Assessment of the 16S-23S rDNA region of Xylella fastidiosa strains to analyze the phylogenetic relationship. Rio Claro, Brasil, 62p. (M.Sc. Dissertation. Instituto de Biociências. UNESP). Available on http:/www.biblioteca.unesp.br

25. Miranda, V.F.O.; Easy Align, versão 1.0. Universidade Estadual Paulista, Rio Claro, Brasil, (2002) Available from em: <http:// www.rc.unesp.br/xivsbsp/ealign/>.

26. Page, R.D.M. (1998) TreeView Tree drawing software for Apple Macintosh and Microsoft Windows, version 1.5.2. Institute of Biomedical \& Life Sciences, University of Glasgow, Scotl., UK.

27. Page, R.D.M.; Holmes, E.C. (1998) Molecular Evolution: A Phylogenetic Approach, Blackwell Science Ltda., Oxford, UK.

28. Pooler, M.R.; Hartung, J.S. (1995) Genetic relationships among strains of Xylella fastidiosa from RAPD-PCR data. Curr. Microbiol., 31, 134-137.

29. Rogall, T.; Wolters, J.; Flohr, T.; Bottger, E. (1990) Toward a phylogeny and the definition of species at the molecular level within the genus Mycobacterium. Int. J. Syst. Bacteriol., 40, 323-330.

30. Simposon, A.J.G.; Reinach, F.C.; Arruda, P. et al. (2000) The genome sequence of the plant pathogen Xylella fastidiosa. Nature, 406(13), $151-157$

31. Wells, J.M.; Raju, B.C.; Hung, H.Y.; Weisbrug, W.G.; Mandelco-Paul, L.; Brenner, D.J. (1987) Xylella fastidiosa gen. nov., sp. nov. Gramnegative, xylem limited, fastidious plant bacteria related to Xanthomonas spp. Int. J. Syst. Bacteriol., 37, 136-143.

32. Wheeler, W.C. (1996) Optimization alignment: the end of multiple sequence alignment in phylogenetics? Cladistics, 12: 1-9, 1996.

33. Wheeler, W.; Gladstein, D. (1991-1998) Malign, versão 2.7. American Museum of Natural History, New York, USA. 